\title{
Comments on "The drivers of housing cycles in Spain" by Oriol Aspachs-Bracons and Pau Rabanal
}

\author{
Stefano Neri
}

Published online: 19 February 2010

(C) The Author(s) 2010. This article is published with open access at Springerlink.com

\section{Introduction}

It is a great pleasure to have the opportunity to offer my comments on the paper "The Drivers of Housing Cycles in Spain" by Oriol Aspachs-Bracons and Pau Rabanal. The authors address an important and timely question. The sharp contraction in the housing sector is a key feature of the economic downturns in the US, UK, Ireland and Spain. The authors tackle a particularly complex issue as several factors, including monetary policy, the compression of risk premia and financial innovation, are all likely to have played a role. Understanding the role played by low interest rates is of first order importance for policy makers at central banks. In my opinion, the model the authors set up is a good starting point for studying the spillovers from the housing market to the rest of the economy. However, other important features, such as nominal wage rigidities and indexation and credit supply, should be considered in order to enhance the ability of the model to fit the data and to shed light, in particular, on the role of monetary policy in the last housing market cycle in Spain. Overall, I find the empirical analysis presented in the paper valuable and interesting.

\section{Overview of the paper}

Aspachs and Rabanal rely on a two-country, two-sector New Keynesian model of the European Monetary Union in which one country represents Spain and the other the I wish to thank Oriol and Pau for providing me with the time series of the innovations to the housing
demand shock. The views expressed in this discussion do not reflect those of the Banca d'Italia.

This commentary refers to the article available at: doi:10.1007/s13209-009-0010-y.

S. Neri $(\bowtie)$

Economic Outlook and Monetary Policy Department, Banca d'Italia, Rome, Italy

e-mail: stefano.neri@bancaditalia.it 
rest of the countries. They estimate the model over the period 1995-2008 using Bayesian methods and carry out some exercises that are meant to understand the "drivers" of the housing cycle in Spain. The model allows for imperfect labor mobility between the residential and the consumption sectors and for sticky prices. The role of borrowing constrained households is considered in Sect. 4 of the paper in which the robustness of the results is tested. Two-sector models with constrained households have been shown to be able to explain several features of the data such as the response of residential investment and consumption to monetary policy and housing demand shocks (Monacelli 2007; Iacoviello and Neri 2010). The authors put forward two potential explanations for the housing boom in Spain. According to the first one, the decline of interest rates during the run up to the establishment of the European Monetary Union in 1999 created the conditions for a strong expansion of demand for housing. The second explanation relates to demographic trends and population growth which was faster in Spain than in other EMU countries, partially reflecting immigration. The model allows for these two possible explanations as it incorporates monetary policy and housing preference shocks. The latter shocks can be seen as capturing in reduced form all the factors affecting aggregate demand for housing that are not explicitly modeled, including demographic ones. The variance decomposition (Table 4 in the paper) is used to assess the relative importance of monetary policy and housing demand shocks for both residential investment and real house prices. While the first shock explains a negligible fraction of the variability of both variables, shocks to preferences account for a large fraction, around 50 and $35 \%$ of the fluctuations of, respectively, prices and quantities. The key result of the paper is that monetary policy did not contribute to the housing cycle while demand factors were responsible for the boom and the bust. In light of these results, a natural question arises. Could the limited role of monetary policy be a consequence of the weak propagation mechanism as several real and nominal frictions (i.e., nominal wage rigidities and indexation to inflation), which have been shown to be important in accounting for the delayed effects of policy shocks (Christiano et al. 2005), are missing from the model. Could the model be misspecified in such a way that it is not able to disentangle the two explanations? To put it in other words, could it be possible that the housing preference shifter captures also the effects of monetary policy? I address this concern in the next section.

\section{Housing demand shocks: what do they capture?}

In order to understand whether the estimated innovations are correlated with demographic variables I estimated the following equation (Evans 1992; Iacoviello and Neri 2010):

$$
u_{t}^{j}=A(L) u_{t-1}^{j}+B(L) x_{t-1}+v_{t}
$$

where $v_{t}$ is a mean zero, i.i.d. normally distributed random variable and $A(L)$ and $B(L)$ are polynomials in the lag operator $L$. I include in the vector $x_{t}$ the following variables: total population growth (source National Accounts), immigrants population growth (annual data, linearly interpolated to the quarterly frequency; source INE, Instituto Nacional de Estadistica), the real 3-month interest rate (the nominal rate, source ECB, 
Table 1 Predictability of housing preference innovations

\begin{tabular}{llll}
\hline Variable & Coefficient & $t$-Statistic & Significance level \\
\hline Immigrant population growth & 0.119 & 3.546 & 0.0004 \\
3-Month real interest rate & -1.457 & 3.138 & 0.0017 \\
Securitisation (\% loans) & 0.543 & 2.100 & 0.0349 \\
Lagged innovations & -0.379 & -2.42 & 0.0155 \\
Sample period & $1999: \mathrm{Q} 2-2008: \mathrm{Q} 2$ & & \\
$N$ observation & 37 & & \\
$R^{2}$ & 0.42 & & \\
Ljung-box $Q$-statistic & 0.57 & & \\
(autocorrelation residuals) & & & \\
\hline
\end{tabular}

Heteroskedasticity and autocorrelation consistent (HAC) standard errors

minus Consensus forecast inflation expectations) and the ratio of securitised loans to total loans to the private sector (source ECB). The first two variables are meant to capture demographic factors behind housing demand. The real interest rate is introduced in order to assess the likely misspecification of the model concerning the transmission mechanism of monetary policy. A statistically significant coefficient on this variable would highlight an important misspecification of the model. Finally, the last variable may capture the effects of financial innovation on housing demand. In Table 1 I report the results from the best specification (all coefficients are significant at the 5\% confidence level) of Eq. (1) in which I have used one lag for each explanatory variable and one lag of the estimated innovations.

The Table shows that the variables I considered have the expected signs and are all significant at the 5\% confidence level. On the contrary, total population growth is not significant. The $R^{2}$ is 0.42 . An increase in immigrants population, a low short-term real interest rate and a higher level of securitisation are all associated with an increase in the demand for housing, consistently with my a priori. If I exclude the lag of the innovations from the regression the fit worsen (the $R^{2}$ falls to 0.33 ); however, immigrant population growth and the real interest rate are both still significant while this is not the case for securitisation. If I include the mortgage rate (source Banco de España) instead of the real interest rate, the fit increases to 0.45 . Figure 1 plots actual and fitted values from the preferred regression.

The take-away message is the following. While it is good news that the housing preference shock captures demographic factors, it is bad news to find that the shortterm real interest rate, which is controlled by monetary policy, has predictive power for housing demand. This finding suggests that it may be worth checking whether these results still go through once other real and nominal frictions are added to the model in order to improve the transmission mechanism of monetary policy.

\section{Conclusions}

To conclude, the paper provides an important attempt to understanding the drivers of the housing market in Spain over the last decade. The topic is highly relevant since 


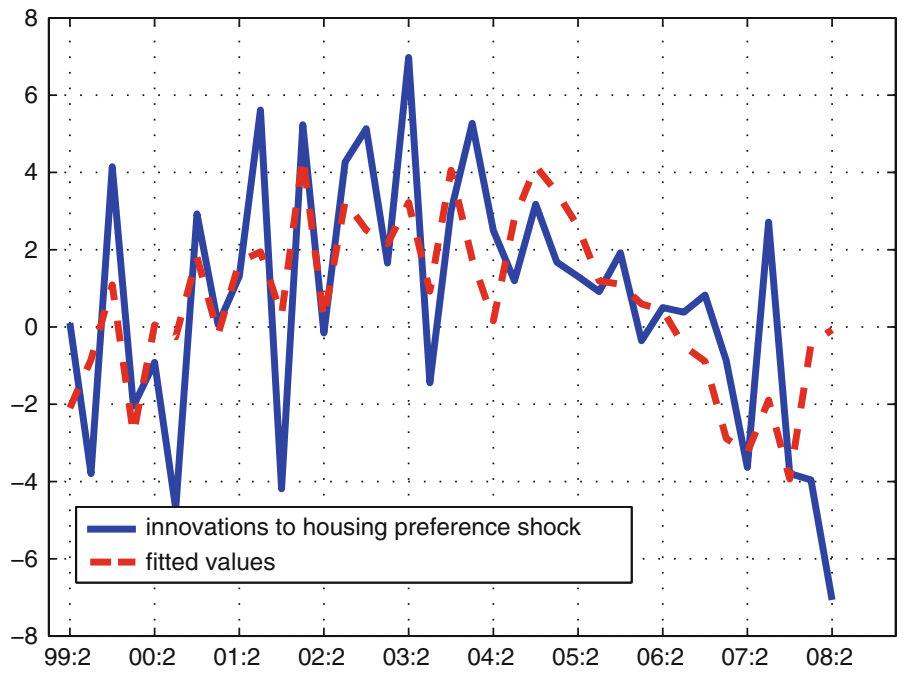

Fig. 1 Actual innovations to the housing preference shock and fitted values

the rapid and sharp correction in the housing market has led to a strong increase in the unemployment rate and in mortgages foreclosures. However, more effort should be devoted in future research in better modeling the transmission mechanism of monetary policy, possibly by including a banking system and the supply of credit, and other rigidities. The paper by Aspachs and Rabanal constitutes an important first step in the direction of understanding the role of housing markets in a monetary union. I look forward to future research on this topic.

Open Access This article is distributed under the terms of the Creative Commons Attribution Noncommercial License which permits any noncommercial use, distribution, and reproduction in any medium, provided the original author(s) and source are credited.

\section{References}

Aspachs-Bracons O, Rabanal P (2010) The drivers of housing cycles in Spain. La Caixa Working Paper Series 02/2009. SERIEs 1:101-130

Christiano LJ, Eichenbaum M, Evans CL (2005) Nominal rigidities and the dynamic effects of a shock to monetary policy. J Polit Econ 113(1):1-46

Evans CL (1992) Productivity shocks and real business cycles. J Monet Econ 29(2):191-208

Iacoviello M, Neri S (2010) Housing market spillovers: evidence from an estimated DSGE model. Am Econ J Macroecon (forthcoming)

Monacelli T (2007) Keynesian models, durable goods, and collateral constraints. J Monet Econ 56(2):242254 